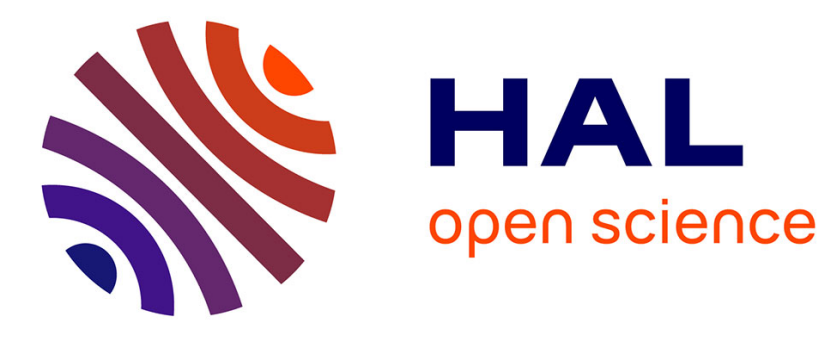

\title{
Sentinel-1 monitoring of Santorini volcano post-unrest state
}

\author{
Elena Papageorgiou, Michael Foumelis, Antonios Mouratidis, Costas \\ Papazachos
}

\section{- To cite this version:}

Elena Papageorgiou, Michael Foumelis, Antonios Mouratidis, Costas Papazachos. Sentinel-1 monitoring of Santorini volcano post-unrest state. IGARSS 2018 - 2018 IEEE International Geoscience and Remote Sensing Symposium, Jul 2018, Valencia, France. pp.1577-1580, 10.1109/IGARSS.2018.8518471. hal-02734492

\section{HAL Id: hal-02734492 https://hal-brgm.archives-ouvertes.fr/hal-02734492}

Submitted on 2 Jun 2020

HAL is a multi-disciplinary open access archive for the deposit and dissemination of scientific research documents, whether they are published or not. The documents may come from teaching and research institutions in France or abroad, or from public or private research centers.
L'archive ouverte pluridisciplinaire HAL, est destinée au dépôt et à la diffusion de documents scientifiques de niveau recherche, publiés ou non, émanant des établissements d'enseignement et de recherche français ou étrangers, des laboratoires publics ou privés. 


\title{
SENTINEL-1 MONITORING OF SANTORINI VOLCANO POST-UNREST STATE
}

\author{
Elena Papageorgiou $^{(1)}$, Michael Foumelis $^{(2)}$, Antonios Mouratidis $^{(1)}$, Costas Papazachos $^{(1)}$ \\ ${ }^{(1)}$ School of Geology, Aristotle University of Thessaloniki, Greece, \\ e-mail: elenpapageo@geo.auth.gr \\ ${ }^{(2)}$ BRGM - French Geological Survey, Orleans, France
}

\begin{abstract}
At the beginning of 2011 Santorini volcano underwent a volcanic unrest, accompanied by an increase of the microseismic activity. The unrest that lasted for over a year, demonstrated substantial amounts of uplift, justifying the volcanic origin of the activity. The continuation of the deformation monitoring after the unrest event was deemed necessary, in order to validate the post-unrest state of the volcano and to recognize potential ground deformation signals. The Copernicus Sentinel-1 mission is profoundly promising towards this direction, due to its systematic acquisition and short revisit. A multi-temporal SAR interferometric analysis was deliberated in a way to avoid significant phase changes and to retain high coherence. In this paper, DInSAR analysis was applied over Santorini to retrieve the actual deformation state of the volcano during the repose period 2014-2017. The results indicate subsidence rates on Nea Kameni of about $8-9 \mathrm{~mm} / \mathrm{yr}$, implying a gradual deflation of the magma chamber, while the rest of the area appears almost stable with negligible deformation.
\end{abstract}

Index Terms - Copernicus Sentinel-1, SAR Interferometry, ground deformation, Santorini volcano.

\section{INTRODUCTION}

Differential SAR Interferometry (DInSAR) techniques are widely used to measure and monitor ground deformations on volcanoes. The systematic monitoring over Santorini volcano, since 1992, provided new insights on the spatial distribution of the volcano's deformation [1]-[4].

Since its last eruption in 1950, Santorini volcano remained in a dormant state until 2011, when seismo-volcanic activity was detected and recorded by local seismic monitoring networks. This is evidenced by Synthetic Aperture Radar Interferometry (InSAR) measuring a gradual deflation signal over Nea Kameni with low rates of about 5-6 mm/yr [1]-[4] for the period 1992-2010, as well as by the low background seismicity within the caldera [5]. At the beginning of 2011 the volcano showed signs of unrest with increased microseismic activity [6], [7], and significant ground uplift, reaching $14 \mathrm{~cm}$ within a year [3]. ALOS PALSAR data indicate the onset of the phenomenon in early 2010, where an aseismic pre-unrest phase of increased subsidence (1-3 $\mathrm{cm})$ preceded the uplift [3].

Copernicus Sentinel-1 mission enabled the systematic monitoring, due to the significantly improved temporal sampling. Sentinel-1 constellation consists of a pair of Cband Synthetic Aperture Radar (SAR) imaging satellites that ensure the continuity of Europe's C-band SAR data and build on the heritage of ESA's ERS and ENVISAT SAR missions. The revisit time of Sentinel-1, 6 days in equatorial regions, offered a long-term data archive, which is required to obtain further information on the long-term behaviour of the volcano and to provide in particular its cycling sequence of possible inflation and deflation processes. The Interferometric Wide (IW) swath of Sentinel-1, the default acquisition mode for Interferometry monitoring, covers a width of $250 \mathrm{~km}$ at $5 \mathrm{~m}$ by $20 \mathrm{~m}$ spatial resolution. The IW mode captures three sub-swaths using the Terrain Observation with Progressive Scans (TOPS) imaging mode that requires specific interferometric handling [8].

This work focuses on the operational use of the Sentinel-1 SAR mission and aims to provide the monitoring of ground deformation on Santorini, as well as the evaluation of the volcano status following the unrest period of 2011-2012.

\section{VOLCANIC SETTING}

Volcanism in Santorini evolved successively from the formation of volcanic cones, two explosive cycles of pyroclastic eruptions, the collapse of the caldera and the development of shield volcanoes within the caldera [9]. As a result, a peculiar volcanic configuration was finally set, with two very active volcanoes, the Nea Kameni volcano located at the center of the caldera and the Columbos submarine volcano located almost $7 \mathrm{~km} \mathrm{NE}$ of Thera (Fig. 1). The development of Santorini has been strongly influenced by the regional faults of the area, namely the Kameni and 
Columbos Fault Zones (KFZ, CFZ) [9], [10]. These mark the alignment of several eruptive vents and have been interpreted to comprise major normal faults [11]. The largest volcanic eruptions on SVC date to 197 BC, 1866, 1925 and 1949-1950 and are all associated with Nea Kameni volcano. However, the eruption in $1650 \mathrm{AD}$ took place offshore at Columbos volcano [12].

At the beginning of 2011 an increased seismic activity of relatively low intensity $(\mathrm{ML}<3.2)$ began within the intracaldera area, surrounding Nea Kameni volcano and Thera [6], [7], indicating the onset of an unrest episode that started in 2011 and lasted up to the first half of 2012 [1]-[4].

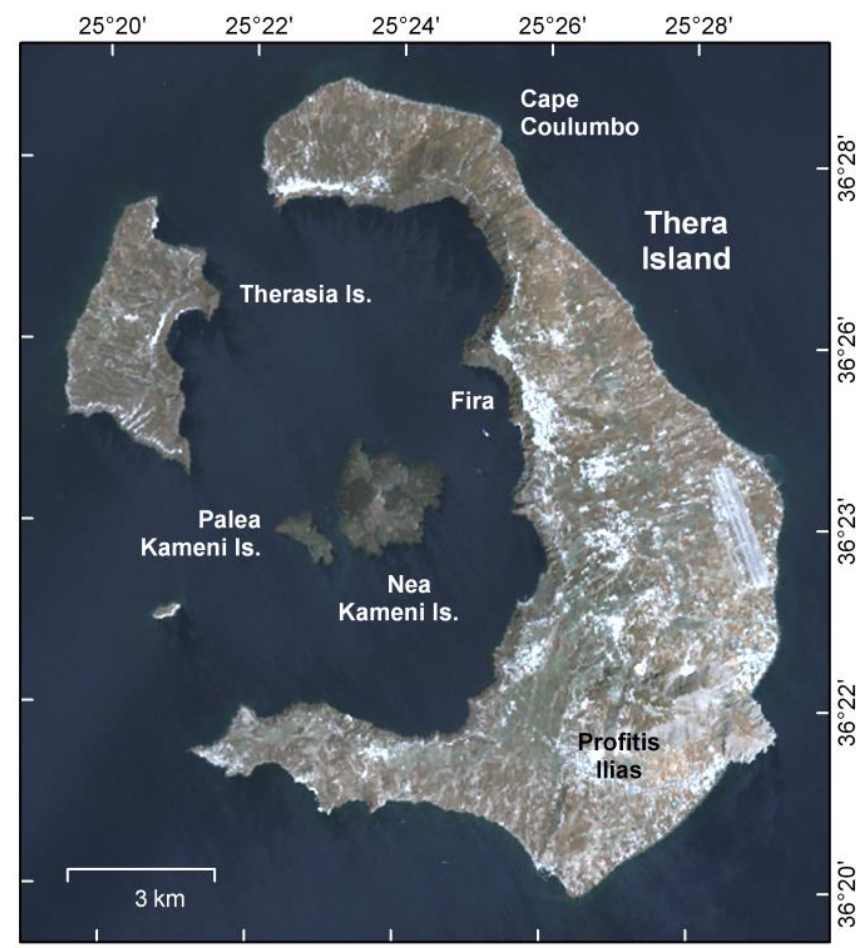

Fig 1. Santorini Volcano Map

\section{METHODOLOGY}

Both ascending and descending orbit geometries of Sentinel1 were used for the interferometric analysis of Santorini volcano, covering the period from October 2014 to September 2017. For the ascending orbit (relative number 29) a total of 81 TOPS SAR acquisitions were utilized, whereas for the opposite orbit (relative number 109) 83 acquisitions were used.

For InSAR processing and analysis, a workflow using GAMMA s/w package was implemented [13]. Taking into account the short revisit time of Sentinel-1 data, interferograms of short temporal span were considered in order to retain high coherence and to minimize the temporal decorrelation effects. Under this approach, the long-term monitoring of a dense temporal stack gave the opportunity to recognize and avoid unwrapping artifacts, and to characterize the spatio-temporal behavior of the deformation signal.

For the interferometric processing of Sentinel-1 TOPS data, the accurate co-registration is considered to be a crucial step. Due to TOPS characteristics, additional processing steps are required to properly handle burst-type imagery with respect to the standard StripMap acquisitions [14]. Since accuracy at 0.005 pixel level is required, coregistration is performed on a pixel basis using initially orbital information and DEM-assisted cross-correlation methods, while an iterative refinement procedure is followed, by using the Enhanced Spectral Diversity technique [15].

To mitigate signal variability, multi-looking by $6 \times 2$ factors in range and azimuth respectively was considered during interferometric processing, whereas final results were geocoded at $30 \mathrm{~m}$ spacing. Topographic phase was simulated and subtracted based on a $20 \mathrm{~m}$ resolution Digital Elevation Model (DEM) generated from 1/50.000 scale topographic map of the Hellenic Military Geographical Service (HGMS).

A fundamental aspect of the processing scheme was to obtain a redundancy of the interferometric pairs. The final selection of the interferograms was made by constraining the maximum temporal baseline, as well as by using an upper threshold on the maximum normal baseline value. The selected maximum temporal baseline was set to 180 days and the maximum normal baseline at $30 \mathrm{~m}$, resulting in 296 and 305 differential interferograms for the ascending and descending geometry, accordingly. A common reference area located at Profitis Ilias Mt. was considered during phase unwrapping. Finally, the successfully unwrapped interferograms were further analyzed by averaging through Interferometric Stacking (IS) [16].

\section{RESULTS-DISCUSSION}

The interferometric analysis of the Sentinel-1 TOPS data allowed studying the post-unrest deformation of Santorini volcano. Sentinel-1 IS results are shown in Fig. 2 and Fig. 3, presenting the Line-Of-Sight (LOS) deformation rates for the ascending and descending orbits, respectively. Similar subsidence rates of about $8-9 \mathrm{~mm} / \mathrm{yr}$ are indicated on Nea Kameni, for both acquisition geometries. Although maximum deformation rates are comparable for the two orbits, deformation does not follow exactly the same pattern. Therefore, the southwestern part of Nea Kameni seems to be 
most affected in the ascending orbit, while in the descending orbit maximum deformation seems to be shifted to the central part. This could imply the contribution of the

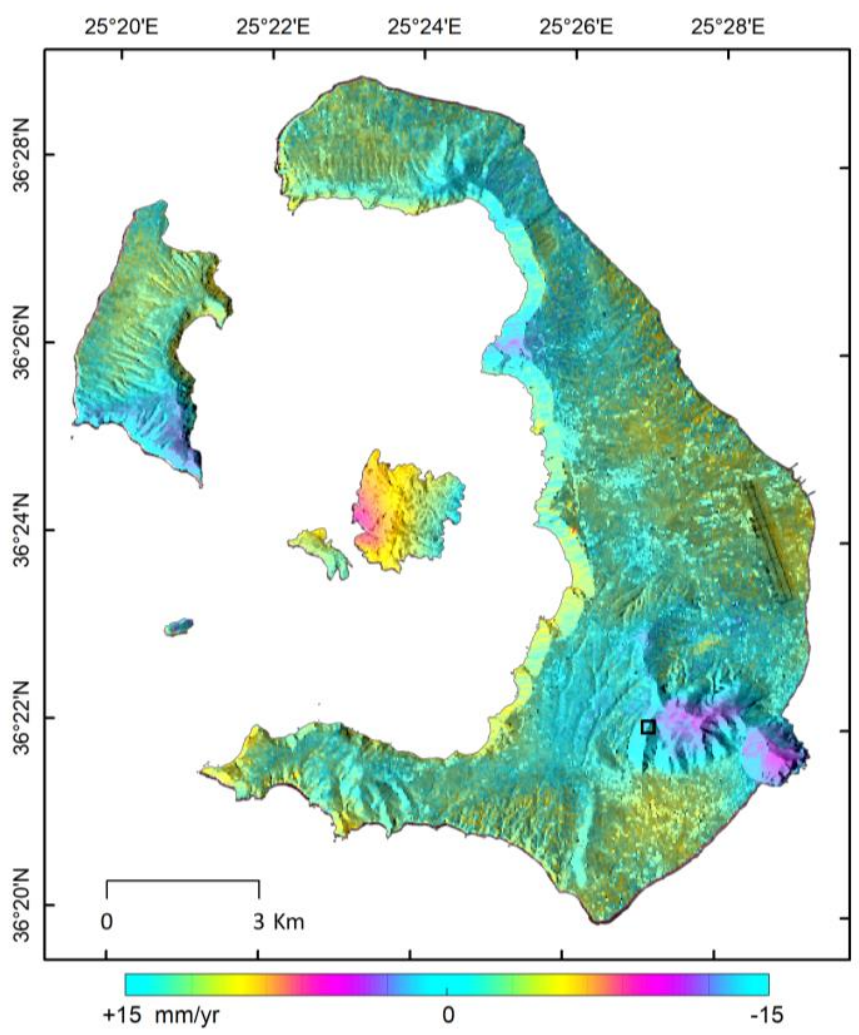

Fig 2. Sentinel-1 LOS deformation rates for the ascending acquisition geometry (Oct. 2014-Sept. 2017). In background the average multi-looked SAR intensities. The selected reference point is shown in square.

Given the amount of data and the time span of the observations, measurement uncertainties were maintained at a level of less than $1 \mathrm{~mm} / \mathrm{yr}$ for both orbits. Additionally, the high coherence levels over Nea Kameni underline the robustness of the results.

While subsidence of approximate $5 \mathrm{~mm} / \mathrm{yr}$ is described on Nea Kameni for the period prior to the unrest (1992-2010) using ERS and ENVISAT data [2], [3], the volcano seems to be yet again subsiding during the post-unrest phase (20142017), but with almost doubled rates. Apart from the differences in the deformation rates, the overall deformation pattern is retained.

It is worth mentioning that although the areas most affected by the unrest were Nea Kameni and Cape Skaros, herein, during the monitoring period 2014-2017, deformation patterns were recognized on Nea Kameni, whereas Cape Skaros appears to be quite stable. horizontal component of motion. The rest of the volcano indicates minor deformation rates not exceeding 2-3 $\mathrm{mm} / \mathrm{yr}$.

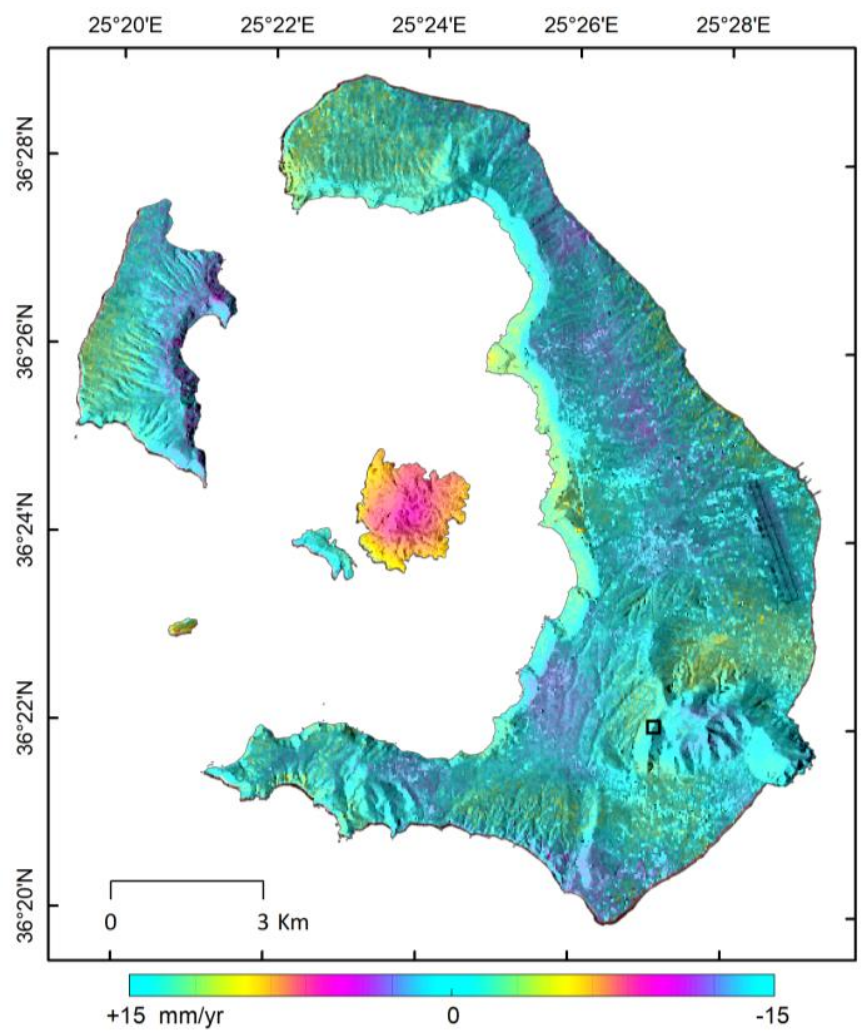

Fig 3. Sentinel-1 LOS deformation rates for the descending acquisition geometry (Oct. 2014-Sept. 2017). In background the average multi-looked SAR intensities. The selected reference point is shown in square.

\section{ACKNOWLEDGMENTS}

This work is realized in the framework of "Human Resources Development Program, Education and Lifelong Learnings", of the State Scholarships Foundation of Greece, co-financed by the European Social Fund-ESF and the Greek Government.

\section{REFERENCES}

[1] Papageorgiou E., Foumelis M. \& Parcharidis Is., 2011. SAR Interferometric analysis of ground deformation at Santorini Volcano (Greece). Proceedings of Fringe 2011 Workshop, (ESA SP-697, January 2012), Frascati, Italy.

[2] Papageorgiou E., Foumelis M. \& Parcharidis Is., 2012. Longand Short-Term Deformation Monitoring of Santorini Volcano: Unrest Evidence by DInSAR Analysis. IEEE Journal of Selected 
Topics in Applied Earth Observations \& Remote Sensing (JSTARS), vol. 5, no 5, 1531-1537.

[3] Foumelis M., Trasatti E., Papageorgiou E., Stramondo S. \& Parcharidis Is., 2013. Monitoring Santorini Volcano (Greece) Breathing from space. Geophysical Journal International, doi: 10.1093/gji/ggs135.

[4] Parks, M. M., et al. (2012), Evolution of Santorini Volcano dominated by episodic and rapid fluxes of melt from depth, Nat. Geosci., 5(10).

$749-754$.

[5] Dimitriadis, I., Karagianni, E., Panagiotopoulos, D., Papazachos, C., Hatzidimitriou, P., Bohnhoff, M., Rische, M. \& Meier T. (2009). Seismicity and active tectonics at Coloumbo Reef (Aegean Sea, Greece): Monitoring an active volcano at Santorini Volcanic Center using a temporary seismic network. Tectonophysics 465, 136-149.

[6] Aristotle University of Thessaloniki (2005), Seismicity Catalogs. Available at: http://geophysics.geo.auth.gr/the_seisnet/WEBSITE_2005/ station_index_en.html.] Last accessed 20th May 2013.

[7] Hellenic seismological broadband network (NOA_HL), Catalogue of revised locations. Institute of Geodynamics, National Observatory of Athens (NOA). [Online]. Available: http://bbnet.gein.noa.gr

[8] P. Prats-Iraola, M. Nannini, R. Scheiber, F. De Zan, S. Wollstadt, F. Minati, M. Costantini, A. Bucarelli, S. Borgstrom, T. Walter, M. Foumelis and Y-L. Desnos "Sentinel-1 assessment of the interferometric wide-swath mode", IGARSS 2015, 5248-5251, 2015

[9] T. H. Druitt, R. A. Mellors, D.M. Pyle, and R. S. J. Sparks, "Explosive volcanism on Santorini, Greece," Geol. Mag., vol. 126, pp. 95-126, 1989.

[10] D. Sakellariou, H. Sigurdsson, M. Alexandri, S. Carey, G. Rousakis, P. Nomikou, P. Georgiou, and D. Ballas, "Active tectonics in the Hellenic volcanic Arc: TheKolumbo submarine volcanic zone," Bull. Geol. Soc. Greece, vol. XLIII, no. 2, pp. 1056-1063, May 2011.

[11] G. Pe-Piper and D. J.W. Piper, "The SouthAegean active volcanicArc: Relationships between magmatism and tectonics," Develop. Volc., vol. 7, pp. 113-133, 2005.

[12] F. Fouqué, "Santorin et ses eruptions," in Masson Et Cie. Paris, 1879 , pp. $1-440$.

[13] U. Wegmüller, C. Werner, and T. Strozzi, "SAR interferometric and SAR differential interferometric processing chain," in Proc. IGARSS, 1998, vol. 2, pp. 1008-1106

[14] Yague-Martinez, N., Prats-Iraola, P., Rodriguez Gonzalez, F., Brcic, R., Shau, R., Geudtner, D., Eineder, M., Bamler, R. Interferometric Processing of Sentinel-1 TOPS Data. IEEE TGRS, 2016. 54(4), 2220-2234.
[15] Scheiber, R., Moreira, A. Coregistration of interferometric SAR images using spectral diversity. IEEE TGRS, 2000. 38 (5), 2179-2191.

[16] T. Strozzi, U. Wegmüller, C. Werner, and A. Wiesmann, "Measurement of slow uniform surface displacement with $\mathrm{mm} /$ year accuracy," in Proc. IGARSS'00, Honolulu, Hawaii, Jul. 2000, pp. 24-28. 